\title{
Mowing: An important part of integrated weed management
}

\author{
By Roger L. Sheley, Kim M. Goodwin, and Matthew J. Rinella
}

$\mathrm{F}$ ew studies have been conducted on the effects of mowing plant communities and noxious weeds, and virtually no long-term studies have been conducted on rangeland. The ecological basis of mowing to manage noxious weeds and to favor desired plants is conclusive. Since leaves collect carbon dioxide and sunlight, defoliation alters plant competitive abilities. Mowing undesired plants decreases their competitive abilities and favors desired plants if proper timing, frequency, and height of mowing are considered for each vegetative situation. This usually is based on the growth rates and growth stage of vegetation.

To reach the goal of establishing a healthy plant community and meet other objectives such as providing forage for livestock and wildlife, an integrated weed management plan should be developed, with the goals and objectives of the particular area in mind. In many cases, mowing can be a valid component in an integrated plan to achieve these goals.

However, it is important to use an integrated plan while testing various mowing strategies to determine the most effective treatment for a given situation. Following are considerations to take into account when developing a mowing program as part of an integrated weed management plan.

\section{Timing}

Properly timed mowing can suppress noxious weeds while favoring desired plants. Timing is primarily based on the growth stage of the weeds targeted and secondarily based on the growth stage of the desired plants. The most effective time to mow weeds is when desired plants are dormant and weeds have reached the early flowering stage.

Mowing during this time can greatly reduce or prevent seed production and weaken the weeds after they have invested a large amount of energy for bolting (when the stem extends from the center of the rosette upwards two to four feet) and producing reproductive structures. Long-term repeated mowing during this stage can eventually deplete root reserves. If regrowth bolts again and produces flowers, an additional mowing is necessary for the process to be effective.

Caution: If performed during the seeding period, mowing can facilitate weed seed dispersal.

Mowing when desired plants have reached dormancy but weeds are flowering can decrease weed competition and allow desired plants to grow unrestricted, producing seed for next year's stand. Desired plants, such as grasses, have equal amounts of growth above and below ground. When grasses are mowed during the growing season, the stress reduces vigor and competitive abilities.

When determining the proper mowing time, first make sure weeds are at the early flowering stage and, when possible, desired plants have reached dormancy. If desired vegetation cover is inadequate (usually less than 20 percent), you may need to revegetate the area.

Effective mowing of large infestations is a longterm commitment. Keep in mind some noxious weeds, such as rhizomatous weeds, have large energy storage capacities. During the first few years, mowing can initially increase infestation stem densities and stimulate growth of root buds in rhizomatous weeds such as Canada thistle. However, over time frequent mowing at each early flowering stage will begin affecting underground reserves and eventually reduce stem densities.

\section{Frequency}

Mowing frequency depends on precipitation and the mowing tolerance of the vegetation. Mowing 
tolerance is a function of relative growth rates, leaf replacement potential, and the ability of the plant to increase photosynthesis after mowing to compensate for leaf loss. Carbon allocation patterns in plants also help determine mowing tolerance. Of particular importance are the number, location, and source of growing points on plant stems. Minimizing removal of desired plant growing points and maximizing removal of undesired plant growing points are central to an effective mowing program.

For annual, biennial and taprooted perennials, the frequency of mowing depends primarily on precipitation. A single midsummer mowing after flower production can reduce or eliminate seed production and shift the balance in favor of desired plants in areas with little or no summer rain.

For example, in 1999 Zollinger and Parker found a single mowing controlled annual sowthistle. Also, in 1990 Roché and Roché found 78 percent control of diffuse knapweed after mowing to a two-inch height each month during the growing season. However, as summer rains increase, regrowth potential increases, and mowing may increase plant vigor and seed production similar to pruning. In such cases, additional mowing will be required.

Rhizomatous weeds usually require more frequent mowing. Repeated mowing is considered an effective control of rhizomatous perennial weeds in alfalfa and many pastures. In 1929 the Ohio Agricultural Experiment Station found mowing three or four times per year nearly eliminated Canada thistle in three years. A 1968 study showed mowing alfalfa two times per year reduced Canada thistle 86 percent after one year and 100 percent after four years. However, other studies suggest mowing Canada thistle kept stands in check but did not eliminate the weed.

\section{Height}

Most grasses can tolerate short mowings once dormant. If the dominant vegetation has not yet shifted to noxious weeds and still contains adequate grass cover, time the mowing so the weeds are at the early flowering stage and the grasses are dormant and have produced seeds.

When the dominant vegetation is a weed, the most effective mowing treatment for control is to mow two inches in height when the weed is at the early flowering stage. However, in some cases, weeds will reach the appropriate stage for mowing but the grasses have not reached dormancy. In such cases, mow the weeds at a height above the desired plants. This is often possible because most noxious weeds will bolt above the grass height and this height can be used to favor grass. It is especially important to mow above desired vegetation if it has not yet dispersed seeds and is not yet dormant.

Defoliating the weeds reduces their vigor and seed production, and increases resources available for neighboring grasses. This also allows the grasses to grow, produce seeds and maintain the vigor needed to minimize reinvasion by noxious weeds.

\section{Take An Integrated Approach}

The pervasiveness and complexity of noxious weeds, combined with their cost of control, necessitates an integrated weed management plan. This type of management plan strives to use the most economic, ecological and environmentally effective

\section{Spotted Knapweed: A case study}

A recent study at Montana State University showed mowing can greatly reduce or diminish seed production and adult spotted knapweed density. The effects of mowing frequency and timing on spotted knapweed and associated desired grasses were studied over three years. The mower was set to cut at 10 inches - this height cut the bolted knapweed plants while passing over desired species, mainly grasses.

The study compared 15 different strategies with varying frequencies and timings of mowing. The mowing treatments were: 1 spring mowing; 1 summer mowing; 1 fall mowing; 2 spring mowings; 2 summer mowings; 2 fall mowings; 1 spring and 1 summer mowing; 1 spring and 1 fall mowing; 1 summer and 1 fall mowing; 1 spring, 1 summer, and 1 fall mowing; 2 spring and 2 summer mowings; 2 spring and 2 fall mowings; 2 summer and 2 fall mowings; 2 spring, 2 summer, and 2 fall mowings; a treatment consisting of mowing at 2 week intervals throughout the growing season; and a control that received no mowing (Table 1).

The study indicated the most effective time to mow spotted knapweed was during the early flowering stage. Mowing at this time decreased adult density by about 85 percent. Seedling density also was reduced. Grasses were only decreased by the most aggressive mowing treatments. 
Table 1. Response of spotted knapweed density to various mowing treatments repeated on two sites in south central Montana.

\begin{tabular}{|c|c|c|c|c|c|c|c|}
\hline \multirow[t]{2}{*}{ Mowing treatment } & \multicolumn{7}{|c|}{ Spotted knapweed density (plants $\mathrm{m}^{-2}$ ) } \\
\hline & $\begin{array}{l}\text { Seedling }^{\mathrm{a}} \\
1997-98\end{array}$ & \multicolumn{2}{|c|}{ Adult } & \multicolumn{2}{|c|}{ Seedling } & \multicolumn{2}{|c|}{ Adult } \\
\hline 1 spring mowing & 504 & 98 & 148 & 20 & 288 & 78 & 130 \\
\hline 1 summer mowing & 135 & 128 & 93 & 18 & 90 & 93 & 175 \\
\hline 2 summer mowings & 152 & 30 & 45 & 35 & 100 & 128 & 148 \\
\hline 2 fall mowings & 303 & 20 & 10 & 98 & 53 & 115 & 30 \\
\hline 1 spring and 1 summer mowing & 172 & 63 & 48 & 8 & 240 & 130 & 178 \\
\hline 1 spring and 1 fall mowing & 448 & $\overline{48}$ & 15 & 90 & 148 & 80 & 23 \\
\hline 2 spring and 2 fall mowings & 119 & 28 & 10 & 33 & 173 & $\overline{48}$ & 8 \\
\hline 2 summer and 2 fall mowings & 213 & 23 & 25 & 25 & 80 & 83 & 53 \\
\hline 2 spring, 2 summer, and 2 fall mowings & 108 & 40 & 18 & 3 & 70 & 43 & 33 \\
\hline 2-week intervals throughout growing season & 91 & 45 & 25 & 3 & 70 & 53 & 50 \\
\hline Non-mown & 382 & 65 & 183 & 93 & 445 & 210 & 205 \\
\hline$\overline{\operatorname{Lsd}}_{0.05}$ & 303 & \multicolumn{2}{|c|}{48} & \multicolumn{2}{|c|}{137} & \multicolumn{2}{|c|}{69} \\
\hline
\end{tabular}

combination of principles, practices, technologies, and systems to meet weed management goals.

Although little research has been conducted into incorporating mowing in an integrated weed management plan, experience provides some practical hints. Some evidence suggests combining mowing with herbicides can enhance perennial weed control. For example, in 1993 Beck and Sebastian demonstrated mowing two or three times a year consistently enhanced Canada thistle control following applications of picloram, picloram $+2,4-\mathrm{D}$, clopyralid $+2,4-\mathrm{D}$, and dicamba. Mowing may also be combined with herbicides over several years. Most weeds grow low to the ground after long-term repeated mowing. In these cases, periodic control through herbicides can remove plants that have acclimated to frequent mowing.

Mowing will not eradicate noxious weeds. However, it can greatly reduce or prevent seed production and significantly stress weeds, providing desired plants a competitive edge, especially when implemented with other methods as part of an integrated noxious weed management plan.
About the authors: Sheley is Associate Professor, Goodwin is Project Specialist, and Rinella was Graduate Research Assistant all with the Department of Land Resources and Environmental Sciences, Montana State University, Bozeman, Mont. 59717.

\section{References}

Beck, K. G. and J. R. Sebastian. 1993. An integrated Canada thistle management system combining mowing with fall-applied herbicides. West. Soc. Weed Sci. Proc. 46: 102-104.

Hodgson, J. M. 1968. The nature, ecology and control of Canada thistle. U.S. Dep. Agric. Tech. Bull. 1386.

Roché, C. T. and B. F. Roché, Jr. 1990. Mowing diffuse knapweed: effects on longevity and seed production. In: Proceedings from Washington State Weed Conference, Washington State Weed Assoc., Yakima, Washington 1923.

Welton, F. A., V. H. Morris, and A. J. Hartzler. 1929. Organic food reserves in relation to the eradication of Canada thistle. Ohio Agric. Exp. Sta. Bull. 441.

Willard, C. J., and R. D. Lewis. 1939. Eradicating Canada thistle. Ohio State Univ. Agric. Coll. Ext. Serv. 146.

Zollinger, R. K. and R. Parker. 1999. Sowthistles. In: R.L. Sheley and J.K. Petroff (eds.), Biology and management of noxious rangeland weeds. Oregon State Univ Press, Corvallis, Oregon 336-349. 